\title{
Production and Technology of Iron and Steel in Japan during 2000
}

\author{
Masayuki HANMYO \\ Chief of Production and Technology Division, The Iron and Steel Institute of Japan, Otemachi, Chiyoda-ku, Tokyo 100-0004, \\ Japan.
}

\section{Economic Circumstance of the Iron and Steel Industry}

The year 2000 showed an upturn instead of the bleak outlook expected earlier. For domestic market, the economic activities evolved in a relatively steady manner, as information technology (IT) industry pulled the facilities investment in the private sector, as automobiles, industrial machines, and electricity showed recovery trend, and as corporate restructuring began to take effect. For export, despite the extensive slowdown of the United States economic growth rate and the decreased export to the United States due to the anti-dumping claim, good results were obtained since there were no breaks in exports to Asia, mainly to Korea and China, excluding Taiwan.

However, consumption remained at low level, and complete unemployment rate was $4.7 \%$, which was the same level as 1999 which marked the worst figure since the survey was started in 1953. The unemployment rate surpassed the United States $(4.0 \%)$ for two years in a row. Number of unemployed was 3.2 million workers, the highest ever recorded, and the severe circumstance continued. Also, the number of employed was 64.46 million workers, which was 0.16 million less workers compared to 1999 , or three years consecutive decrease. Although the number of workers increased in service industries including IT related, as well as transportation and communications, this increase failed to supplement the decrease in construction and manufacture industries.

For investment, although companies continued to take very careful stance toward facilities investment, the bottom seemed to have been hit, and facilities investment of private sectors increased compared to previous year for first time in three years. Particularly, the large increase of investment in IT fields such as semiconductor, electronic parts, and materials pulled the growth in the manufacturing industry.

Looking at the supply and demand for iron and steel, the expectation was not very good compared to 1999 , due to the background of poor conditions including continued slow recovery of domestic steel consumption (sluggish economic recovery; depressed interest in facilities investment; leveling off of activity levels of the manufacture industry including automobile, shipbuilding, electricity, and machinery; and lowered expectation for public works due to compressed budget), as well as changes in the export environment for steel (settling down of exports to Asia which had supported the rapid recovery of iron and steel production, and further decrease of exports to the United States).

However, the preliminary projection was greatly exceeded, and the result was high level for first time in three years, under mild recovery of Japanese economy, supported by solid domestic demand for iron and steel (automobile production recovered to 10 million vehicles in the background of increased domestic sales; commencement of shipbuilding projects also increased steadily; industrial machines recovered; electricity recovered; construction demand, which was expected to be slow, turned out to be recovering steadily as facilities investment increased mainly in the IT industry, and as housing investments recovered due to extended tax reduction for home purchase), as well as extremely good steel export to Asia in the first half of the year, in spite of the outlook for the foothold of domestic and overseas situation was not necessarily optimistic, since there were many obstacles, such as the expansion of domestic overstock and signs of increased steel import from early autumn, as well as rapid deterioration due to economic deceleration in the United States and Asia, and increased worldwide trade protectionism.

Since crude steel production exceeded the initial projection by more than 10 million tons, it was 106.44 million tons, or 12.25 million tons $(13.0 \%)$ increase compared to 1999 , and the 100 million ton level was recovered for first time in three years. By furnace types, L.D converter was 75.78 million tons or $15.8 \%$ increase, electric furnace was 30.66 million tons or $6.7 \%$ increase, and the electric furnace ratio was $28.8 \%$, a four years consecutive decrease. By steel types, ordinary steel was 87.57 million tons or $13.6 \%$ increase, and special steel was 18.87 million tons or $10.2 \%$ increase.

The production of hot-rolled ordinary steel products was 82.89 million tons, which was increase of 9.85 million tons (13.5\%) compared to 1999 , and the 80 million ton level was recovered for first time in three years. Particularly, major steel plate products such as wide strips and heavy/medium plates showed significant growth.

The production of hot-rolled special steel products was 15.75 million tons or 1.52 million tons $(10.7 \%)$ increase, an increase compared to previous years for first time in three years. Therefore, production of total steel products was 98.64 million tons or 11.38 million tons $(13.0 \%)$ increase, and the 90 million ton level was recovered for first time in three years. (Table 1) 
Table 1. Transition of iron, steel and steel main goods production. (unit: 1000 tons)

\begin{tabular}{|c|c|c|c|c|c|c|c|c|c|}
\hline & \multirow{2}{*}{$\begin{array}{c}1997 \\
\text { Total } \\
\end{array}$} & \multirow{2}{*}{$\begin{array}{c}1998 \\
\text { Total } \\
\end{array}$} & \multirow{2}{*}{$\begin{array}{c}1999 \\
\text { Total } \\
\end{array}$} & \multirow{2}{*}{$\begin{array}{c}2000 \\
\text { Total }\end{array}$} & \multicolumn{4}{|c|}{2000} & \multirow{2}{*}{$\begin{array}{c}(2000-1999) \\
(\%) \\
\end{array}$} \\
\hline & & & & & Jan-March & April-June & July-Sept. & Oct.-Dec. & \\
\hline Crude steel & 104,545 & 93,548 & 94,192 & 106,444 & 25,400 & 26,713 & 26,952 & 27,379 & 13.0 \\
\hline By B.O.F & 70,295 & 63,716 & 65,452 & 75,784 & 18,084 & 18,780 & 19,453 & 19,467 & 15.8 \\
\hline By E.A.F & 34,250 & 29,832 & 28,740 & 30,660 & 7,316 & 7,933 & 7,499 & 7,912 & 6.7 \\
\hline Pig iron by B.F & 78,510 & 74,979 & 74,518 & 81,068 & 19,629 & 20,189 & 20,641 & 20,610 & 8. 8 \\
\hline Hot-rolled ordinary steel & 81,927 & 73,183 & 73,039 & 82,891 & 20,193 & 20,602 & 21,048 & 21,048 & 13. 5 \\
\hline Large H shapes & 8,400 & 7,989 & 6,652 & 7,235 & 1,698 & 1,895 & 1,829 & 1,814 & 8. 8 \\
\hline Medium and Small shapes & 2,044 & 1,699 & 1,636 & 1,755 & 448 & 431 & 405 & 471 & 7. 3 \\
\hline Small bar & 13,019 & 11,881 & 11,850 & 12,247 & 2,925 & 3,089 & 3,062 & 3,171 & 3.4 \\
\hline Wire & 2,981 & 2,864 & 2,896 & 2,736 & 724 & 672 & 682 & 658 & -5.5 \\
\hline Medium \& Heavy plate & 9,127 & 8,246 & 7,629 & 8,618 & 2,050 & 2,072 & 2,249 & 2,246 & 13. 0 \\
\hline Wide hot strip & 40,194 & 35,090 & 36,873 & 44,529 & 10,949 & 11,073 & 11,414 & 11,094 & 20. 8 \\
\hline Hot-rolled special steel & 16,517 & 14,774 & 14,224 & 15,747 & 3,720 & 3,900 & 4,064 & 4,063 & 10.7 \\
\hline Structure & 6,711 & 5,541 & 5,430 & 6,029 & 1,523 & 1,503 & 1,554 & 1,628 & 14. 3 \\
\hline Stainless steel & 3,263 & 2,767 & 2,651 & 3,021 & 706 & 751 & 775 & 790 & 14. 0 \\
\hline Spring and bearing & 1,171 & 996 & 1,008 & 1,172 & 286 & 295 & 294 & 297 & 16. 3 \\
\hline
\end{tabular}

Source: Research and Statistics Dept., Economic and Industrial Policy Bureau, Ministry of Economy, Trade and Industry, "Monthly of Iron and Steel Statistics"

As mentioned above, although the amount marked fairly high level, severe condition continued in terms of price, since there were several tied priced-lowering accompanying the fierce share competition for volume expansion in the major sheet market in Japan, and the sheet price plummeted in Asia (taking the example of hot-rolled coil, the price fell from 280 dollars in the beginning of the year to 190 dollars in the great fall which occurred after summer), and there were move toward anti-dumping lawsuit which followed the price collapse.

The export of all iron and steel products was 29.16 million tons or 0.95 million tons $(3.4 \%)$ increase compared to 1999 , and this was four years consecutive increase. Looking at the details, while pig iron and steel ingot semiproducts decreased greatly, ordinary steel products and special steel products showed increase of over $10 \%$. For ordinary steel products, increase of sheet and plate products (hot-rolled wide strips, galvanized sheets, cold-rolled wide strips, heavy plates, and electrical strips) was remarkable. For country of export, Taiwan and the United States deceased due to the anti-dumping claim, but Korea, China, and Thailand showed two years consecutive increase.

Import was 7.75 million tons or 1.28 million tons $(19.7 \%)$ increase. Looking at the details, it increased overall, and only hot-rolled wide strips and sheet piling showed decrease among ordinary steel products which were major products. By country of import, Korea, Taiwan, and China all increased.

The number of employees working in the iron and steel industry in December 2000 was 191345 workers, which was decrease of about 11000 (5.3\%) workers compared to the end of 1999. Although this was slight deceleration compared to decrease of about 12000 (5.7\%) workers last year, it was an annual decrease of over $5 \%$ seven years consecutively since 1994 . The particulars were decrease of $5.0 \%$ in iron and steel, $5.5 \%$ in processing, and $6.0 \%$ in other fields.

In such severe environment, the blast furnace industries withdrew from unprofitable products, engaged in coopera- tion by product type through OEM, engaged in cooperation by each supplementary division including transportation maintenance, and procurement, and also participated in technological cooperation with overseas iron and steel companies to deal with globalization movement. In the electric furnace industries, business cooperation activities progressed mainly in the Kansai area.

Such activities are expected to continue, as structural change for strengthening the basis of the Japanese iron and steel industry are being conducted to counter fierce competition through further economic globalization, as well as customers' strict supplier selection by selective and concentrated policy.

\section{Technology and Facility}

\subsection{Ironmaking}

Pig iron production in 2000 was 80.97 million tons and increased $8.7 \%$ compared to previous year. Average pig iron productivity was $2.0 \mathrm{t} / \mathrm{m}^{3} \cdot$ day, a major increase from $1.83 \mathrm{t} / \mathrm{m}^{3} \cdot$ day in previous year.

For the state of operation of blast furnaces, Nagoya No. 3 BF, Nippon Steel Corp. was relined in the short-term of just 3 months, to expand the furnace capacity from $3424 \mathrm{~m}^{3}$ to $4300 \mathrm{~m}^{3}$, and then the furnace was blown-in again. Mizushima No. 2 BF, Kawasaki Steel Corp. achieved the record of the longest lifespan in 1999, since its blow-in on March 20, 1979, and it continues to advance the record. For the development of blast furnace technology, Kawasaki Steel Corp. developed new charging equipment system and new casting system and realized those in a practical operation at Chiba No. 6 BF relined in March 1998. In the following experimental operation, high charging ratio of inexpensive raw materials was made possible by stable and accurate burden distribution, and manpower was reduced by remote control and automated operation of casting (see Topics, p. 665). At NKK, new hot metal temperature measurement technology was applied in the blast furnaces of 


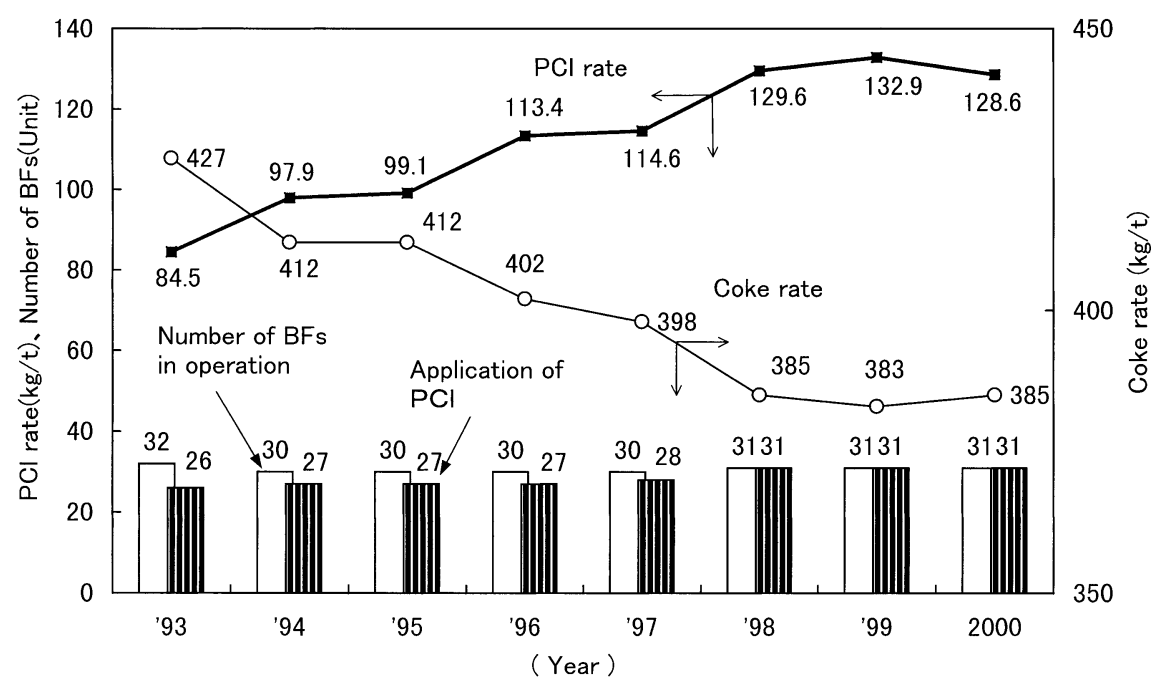

Fig. 1. Increase in pulverized coal rate injected into blast furnace in Japan. Source: The Japan Iron and Steel Federation.

Table 2. Operation performance of converter.

\begin{tabular}{|c|c|c|c|c|c|c|c|c|}
\hline & \multirow{2}{*}{$\begin{array}{l}1997 \\
\text { Average }\end{array}$} & \multirow{2}{*}{$\begin{array}{l}1998 \\
\text { Average }\end{array}$} & \multirow{2}{*}{$\begin{array}{l}1999 \\
\text { Average }\end{array}$} & \multicolumn{4}{|c|}{2000} & \multirow{2}{*}{$\begin{array}{l}2000 \\
\text { Average }\end{array}$} \\
\hline & & & & $\begin{array}{l}\text { Jan.- } \\
\text { March }\end{array}$ & $\begin{array}{l}\text { April- } \\
\text { June }\end{array}$ & $\begin{array}{l}\text { July- } \\
\text { Sept. }\end{array}$ & Oct.-Dec. & \\
\hline Productivity index per steelmaking hour* & 102 & 103 & 104 & 103 & 106 & 108 & 109 & 107 \\
\hline Steelmaking time index per tap to tap* & 100 & 98 & 98 & 101 & 98 & 97 & 97 & 98 \\
\hline Pig iron mixing ratio(\%) & 92.5 & 95.5 & 93.6 & 91.9 & 92.3 & 92.0 & 92.1 & 92.1 \\
\hline Hot metal mixing ratio(\%) & 91.6 & 94.2 & 92.8 & 90.2 & 91.2 & 91.3 & 91.4 & 91.1 \\
\hline Oxygen consumption $\left(\mathrm{Nm}^{3} / \mathrm{t}\right)$ & 58. 7 & 59. 2 & 60.4 & 61.0 & 59. 2 & 59.8 & 58.2 & 59.5 \\
\hline Ratio of continuous cast steel(\%) & 99.1 & 99.2 & 99.3 & 99.3 & 99.3 & 99.3 & 99.2 & 99.3 \\
\hline Ratio of vacuum treated steel(\%) & 61.1 & 61.6 & 62.4 & 63.5 & 62.4 & 63.3 & 64.0 & 63.3 \\
\hline
\end{tabular}

* The index is based on the average of 1994-1996,100

Source: The Iron and Steel Federation

Keihin and Fukuyama Works, the direct temperature measurement of hot metal of tapping hall was realized. And swift and timely furnace heat control reduced administrated values of hot metal temperature and contributed to the improvement of fuel ratio and hot metal quality,

For the pulverized coal injection rate of the blast furnace, as shown in Fig. 1, that in 2000 was $128.6 \mathrm{~kg} / \mathrm{t}$ in average, which was $3.2 \%$ decrease compared to previous year. This was achieved as all companies reduced the fuel ratio to increase the productivity and to intend stable operation of blast furnace on the occasion of the increase of iron production in 2000.

In the development of recycling technology, Nippon Steel Corp. installed a dust recycle facility based on the rotary hearth process in the Hirohata and Kimitsu Works, and put them into operation. In this dust recycle facility, dust generated by blast furnaces and converters which formerly could not be recycled, were dezincified, and high quality reduced iron was produced. This was reused as raw materials in a process of ironmaking and steelmaking (see Topics, $p$. 665). Kawasaki Steel Corp. commenced operation of a coke packed bed type dust smelting furnace, in February 2000, at Mizushima Works. This was a system where metal dust containing zinc and lead, including electric converter dust and shredder dust, was injected in packed bed of coke, and smelting reduction was done in the furnace to separate and collect valuable metal as well as high calorie fuel gas.
In the recycling of waste plastics, Nagoya and Kimitsu Works, Nippon Steel Corp. started operation of "plastics recycling by the coke oven from waste plastics to chemical material" where recycling was accomplished in the coke oven. In this method, pretreated waste plastics was mixed with coal and charged into the carbonization chamber of the coke oven, and reutilized as light oil, coke oven gas, and coke (see Topics, p. 665). For the injection of waste plastics into blast furnace, following NKK Corp., Kobe Steel, Ltd. installed a waste plastics reutilization facility which produced blast furnace raw material from waste plastics at Kakogawa Works, and started injection to No. 3 BF.

\subsection{Steelmaking}

For steelmaking, work performance of converters is shown in Table 2 and work performance of electric furnace is shown in Table 3. The productivity index per steelmaking hour somewhat improved in converters, but continued to decrease in electric furnace.

Secondary refining ratio is shown in Table 4. The ratio of secondary refining on electric arc furnace increased to $93.8 \%$ compared to $92.4 \%$ of previous year.

The ratio of continuously cast steel billet among hotrolling steel ingot is shown in Fig. 2. Ordinary steel increased to $99.7 \%$ compared to $99.6 \%$ of previous year, while special steel decreased to $91.0 \%$ compared to $91.3 \%$ of previous year. 
Table 3. Operation performance of electric furnace.

\begin{tabular}{|c|c|c|c|c|c|c|}
\hline & \multirow{2}{*}{$\begin{array}{c}1997 \\
\text { Average }\end{array}$} & \multirow{2}{*}{$\begin{array}{c}1998 \\
\text { Average }\end{array}$} & \multirow{2}{*}{$\begin{array}{c}1999 \\
\text { Average }\end{array}$} & \multicolumn{2}{|c|}{2000} & \multirow{2}{*}{$\begin{array}{l}2000 \\
\text { Average }\end{array}$} \\
\hline & & & & Jan.-June & July-Dec. & \\
\hline Productivity index per steelmaking hour* & 110 & 111 & 101 & 100 & 104 & 102 \\
\hline Electric power consumption per ton of good ingot $(\mathrm{kWh})$ & 400.9 & 402.5 & 406.8 & 406. 7 & 407.9 & 407.3 \\
\hline Oxygen consumption per ton of good ingot $\left(\mathrm{Nm}^{3} / \mathrm{t}\right)$ & 24. 1 & 22.5 & 20.8 & 20.4 & 20.1 & 20.3 \\
\hline Yield of good ingots $(\%)$ & 91.1 & 91.5 & 91.4 & 91.2 & 91.5 & 91.4 \\
\hline Ratio of good continuously cast steel (\%) & 88.9 & 89.4 & 88. 2 & 87.0 & 87.4 & 87.2 \\
\hline Ratio of alloy steel (\%) & 32.6 & 32.3 & 35.9 & 37.9 & 37.6 & 37.7 \\
\hline
\end{tabular}

* The index is based on the average of 1994-1996,100

Source: The Iron and Steel Federation

Table 4. Secondary refined steel ratio and its trends. (\%)

\begin{tabular}{clcccc}
\hline & & 1997 & 1998 & 1999 & 2000 \\
\hline \multirow{2}{*}{ Converter } & Total secondary refined steel & 79.2 & 79.2 & 80.4 & 80.3 \\
& Vacuum treated steel (out of the above figure) & 61.1 & 61.6 & 62.4 & 63.3 \\
\hline Electric arc furnace & Total secondary refined steel & 91.0 & 92.7 & 92.4 & 93.8 \\
\hline
\end{tabular}

Source: The Iron and Steel Federation

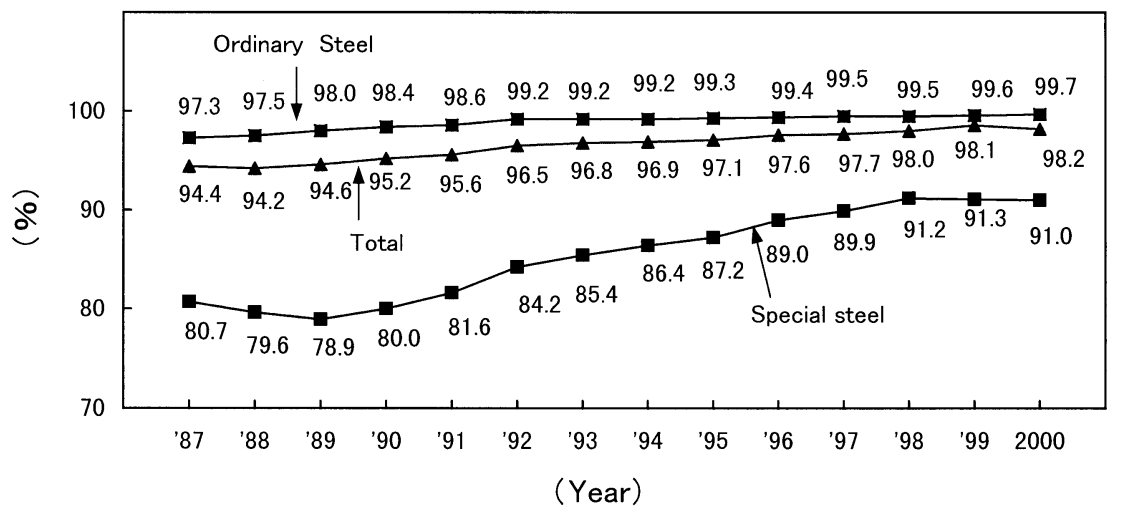

Fig. 2. Change of ratio of continuous casting production. Source: The Japan Iron and Steel Federation.

All companies worked on process optimization to enhance quality, to reduce cost, to promote automation and conservation, and to reduce environmental stress, in order to counter sophistication and inflexibility of market demand, to maintain international cost competitiveness, and to improve work environment.

Improvements in steelmaking process included the following: introduction of iron reserve barrel equipped with induction heaters at Yawata Works, Nippon Steel Corp. (see Topics, p. 666).

Technological developments in the preliminary processing of hot metal included the zero-slag steelmaking process and establishment of technology for utilizing slag as useful material at Keihin and Fukuyama Works, NKK Corp. (see Topics, p. 666).

Activities in continuous casting included the following: commencement of the new No. 2 continuous caster and reconstruction of continuous casters at Kashima Works, Sumitomo Metal Industries, Ltd.; installation of electromagnetic agitation facility in the No. 4 continuous caster at Kakogawa Works, Kobe Steel, Ltd.; and practical operation of quality monitoring system in No. 1 continuous caster at Chita Works, Daido Steel Co., Ltd.

Other activities included the following: the productivity was increased in the 9 ton vacuum induction furnace with the object of increasing melting capacity of value-added high alloy at Shibukawa Works, Daido Steel Co., Ltd.; and actual operation of fully automated raw material mixing system at Takakura Works, Daido Steel Co., Ltd.

In the development of basic technology, research and development for energy rationalizing metal manufacturing process using the electromagnetic power were carried out at the Japan Research and Development Center for Metals (JRCM). This research and development project was scheduled for completion by end of March 2001.

\subsection{Plates; Pipes and Tubes; Sections, Wires, and Rods}

For plates, a hot-rolling plant with state-of-art technology such as oil air lubrication system which does not require oil cellar, was constructed at Funamachi Works, Nakayama Steel Works, Ltd., and commenced commercial production in August 2000. Heavy plates (16-40 mm thickness) and hot-rolled coils (1.6-16 mm thickness) could be produced, and nominal capacity of nearly 0.84 million ton per year was achieved from start (see Topics, p. 667).

At Kashima Works, Sumitomo Metal Industries, Ltd., vertical curved high-speed continuous caster for heavy 
plates commenced operation, and production and distribution was optimized by direct linkage with the heavy plate mill.

For pipes and tubes, a welding pipe and tube facility, where rolling with high diameter shrinkage could be done at warm zone, was installed at Chita Works, Kawasaki Steel Corp. This facility enabled production of both CBR and ERW pipes in one mill. Also, by using fine-grained structural through high diameter shrinkage at warm zone, it enabled manufacture of seam welded steel pipes with both high strength and high ductility. Kawatetsu Steel Tube Co., Ltd. introduced a new roll bending device, in which manufacture of higher strength and higher thickness steel pipes became possible, by lowering the load of upper roll to $1 / 6-1 / 2$ and by optimizing the interval of the lower roll.

For wires and rods, Takasago Works, Kobe Steel, Ltd. developed a local heating rolling method, and improved the surface quality of crank throw. Hitachi Metals, Ltd. developed a new nitrosulphurization method, and increased the lifespan of the mold to two to three times by enhancing the sticking resistance and wear resistance of the mold. Yasuki Plant, Hitachi Metals, Ltd. introduced a hydraulic highspeed four-sided caster for first time in the world, and achieved homogenization to the center of the material.

Chita Works, Daido Steel Co., Ltd. installed a 3500 ton class in-line press to improve product quality, by preliminary forming of the blooming material.

For sections, Fukuyama Works, NKK Corp. installed an on-line accelerated cooling facility, and enabled accelerated cooling of sections steel with complex form, which was difficulty by conventional method.

In other activities, Hoshizaki Works, Daido Steel Co., Ltd. improved its rolling and refining line, and succeeded in improving the accuracy of shape and size of plate for tool steel products, and in substantially shortening the lead time (1/3 of conventional time).

\subsection{Sheets}

\subsubsection{Hot-rolling Process}

Oita Works, Nippon Steel Corp. completed a continuous finish rolling operation, where hot welding was done with $45 \mathrm{~kW}$ carbonic acid gas laser, and produced results in improving quality and productivity.

Fukuyama Works, NKK Corp. installed induction heating device for a crude bar before the finish roller, and attempted improvement of quality and yield by controlling the finishing temperature.

\subsubsection{Cold-rolling Process}

At Toyo Works, Nisshin Steel Co., Ltd., cold rolling line, to which small diameter work roll UC mill was introduced to all stands, commenced operation, and achieved improvement in accuracy of sheet thickness by unique crown control and latest automatic sheet thickness control system.

Hirohata Works, Nippon Steel Corp. manufactured complex high speed tool steel work roll containing $\mathrm{Cr}$, Mo, and $\mathrm{V}$ as jacket material with continuous pouring process for clading (CPC), and applied it to cold rolling for the first time. Thereby, maintenance property of roll surface roughness was improved to prevent slipping by decreased roughness, and continuous, long-duration stable operation was realized.

\subsubsection{Surface Treatment Process}

Fukuyama Works, NKK Corp. developed a steel sheet quality assurance system in which minute defects, which was difficult to detect with conventional device, could be detected with high accuracy and marked automatically, by installing surface inspector using polarizing light source in the continuous galvanizing line (see Topics, p. 667).

Toyo Works, Nisshin Steel Co., Ltd. commenced full operation after completion of galvanizing facility following the cold-rolling facility. Four types of galvanized steel sheets could be manufactured in this line including new galvanized products of zinc, $6 \%$ aluminum, and 3\% magnesium (see Topics, p. 668).

\subsection{Environmental Concerns and Miscellaneous}

In environmental concerns, as technology to decrease burden on the environment toward creation of sustainable circulating society, Nagoya and Kimitsu Works, Nippon Steel Corp. engaged in efficient utilization of waste plastic in coke oven, and Keihin and Fukuyama Works, NKK Corp. increased efficient utilization of waste plastic in blast furnaces responding to full enforcement of Package Recycle Law in April 2000. Also, Chiba Works, Kawasaki Steel Corp. commenced full operation of gasification melting plant by Kawatetsu Thermoselect method to incorporate dioxin countermeasures and recycling, and Takakura Works, Daido Steel Co., Ltd. developed ash melting treatment technology using oxygen burner, where ash generated in the metropolitan garbage incineration facilities were independently melted, with the characteristic of complete melting and complete decomposition of dioxin by burner heating. Also, Chita, Shibukawa, and Tsukiji Works, Daido Steel Co., Ltd. installed radioactivity detector to prevent shipment of scraps polluted with radioactivity, as characteristic measure for hazard prevention in increasing recycling activities.

Other activities included: Sumitomo Metal Industries, Ltd. developed a new tailored blank technique for weight reduction of automobiles (see Topics, p. 669); and Sumitomo Metals (Kokura) Ltd. introduced a RORO ship which eliminated the crane, and achieved large-scale transportation efficiency of 3 times for handling efficiency and 7 times for productivity.

\section{Technology Export and Import}

For the particulars of technological trade in 2000, the results of survey conducted among the supporting member companies of ISIJ are shown in Table 5. The number of technology export was 138 cases compared to 93 cases in previous year, and there were 14 cases of import. Exports were done to Asia and North America which dominated $65 \%$, followed by Middle/South America and Europe. By technological field, $47 \%$ were shaping and processing, $22 \%$ were steelmaking such as electric furnace, and $18 \%$ were overall operation, and these in total dominated $87 \%$. Figure 3 shows the balance of technology trade of the iron and steel industry in from 1995FY to 1999FY.

In the 1999FY, the technology export against payment receipt was about the same as 1998FY, but the technology import against payment receipt decreased, and the amount 
Table 5. Contents of technology export and technology import. (Term: January 1, 2000-December 31, 2000)

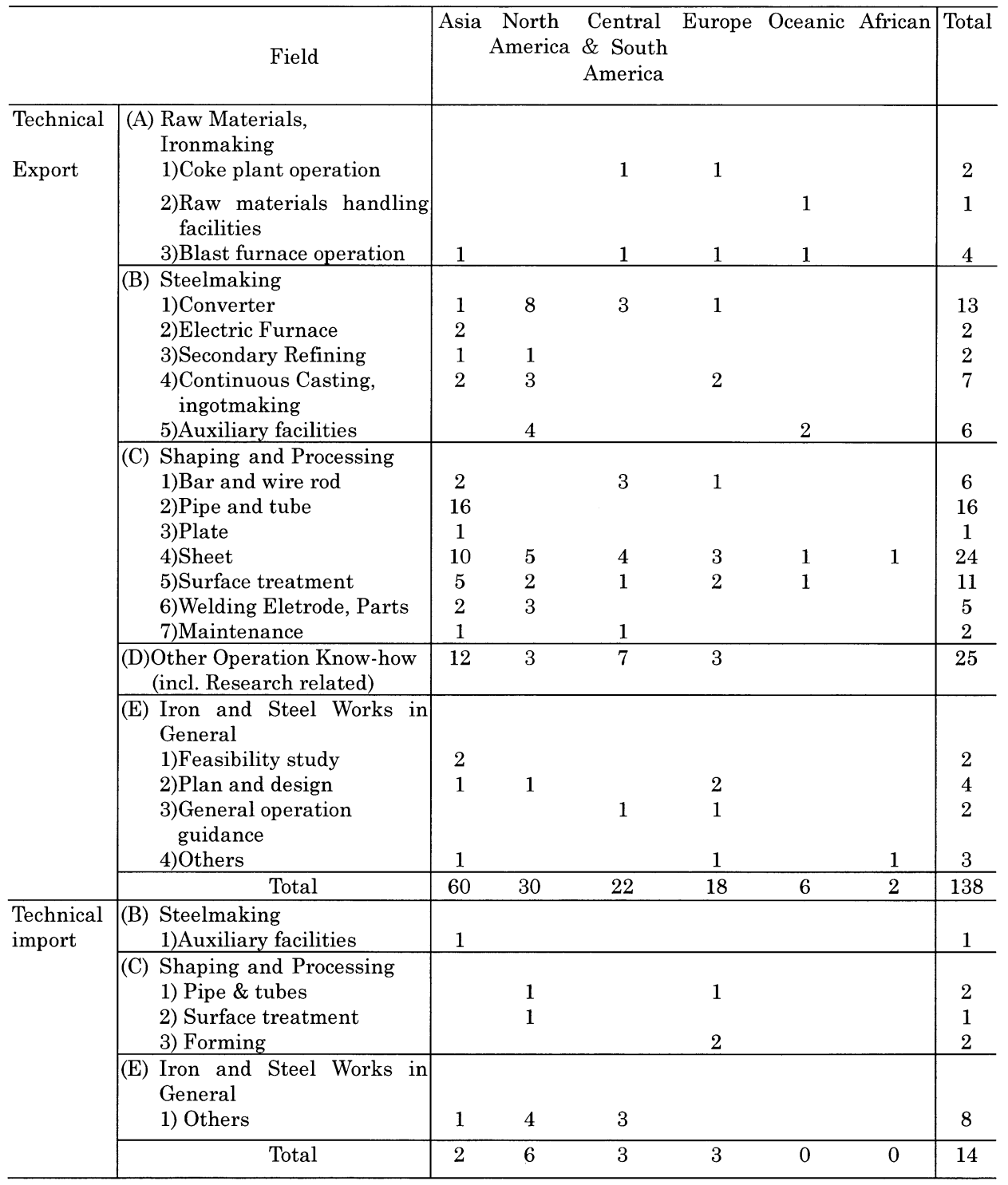

(Coverage: 43 sustaining member companies of ISIJ)
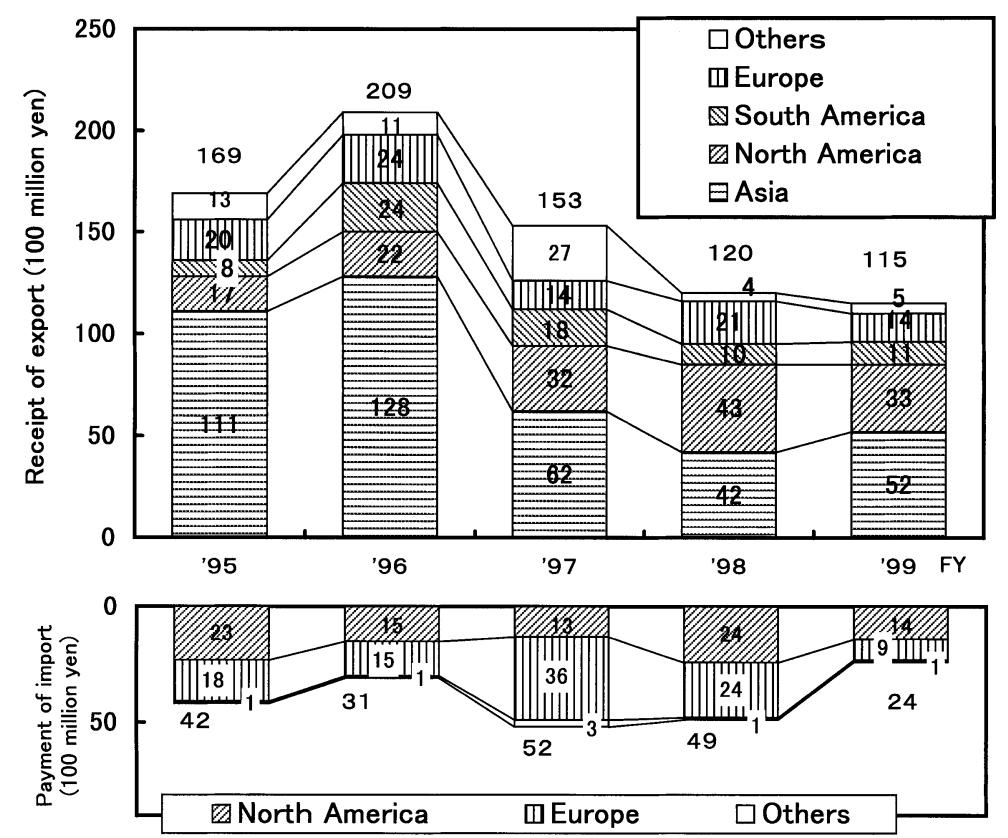

Fig. 3. Balance of technology trade of Steel.

Source: "Report on the Survey of the Research and Development", Statistics Bureau \& Statistics Center. 
of the export-import balance rose from 7.1 billion to 9.1 billion yen.

\section{Research Expenditure}

Figures 4 through 8 show the change in researchers and research expenditure in companies according to "Survey on Science and Technological Research" by Statistics Bureau, Management and Coordination Agency.

For the whole industry, the increase of total company-use research expenditure, which used to be the trend in recent years, stopped, and the decrease trend continued in the iron and steel industry as in FY 1992.

The number of dedicated researchers continued to increase over the years for the whole industry, whereas the decrease trend continued in the iron and steel industry, excluding CY 1998.

Although the ratio of research expenditure against sales for the iron and steel industry was less than $2 \%$ compared to over $3 \%$ for the whole industry. Here, it was decrease for both whole industry and iron and steel industry in FY 1997 and 1998, but 1999 showed a downturn for both industries.

The research expenditure per dedicated researcher was higher for iron and steel industry compared to the whole industry, but both showed decrease trend in FY 1999 compared to previous year.

The number of dedicated researchers per 10,000 workers tended to increase for both the whole industry and the iron and steel industry in CY 1999 and 2000. Combined with Fig. 5, it can be seen that the decrease in number of researchers was small compared to the decrease of all workers in the iron and steel industry.

\section{Creation of New Technology at the ISIJ}

At the ISIJ, research activities for the iron and steel production technology are conducted by the Technical Society, and the organizations are listed in Table 6.

(Academic research for iron and steel are conducted at the Technical Division of the Academic Society, as well as in Forums etc. which are subordinate organizations of the Academic Society.)

\subsection{Technical Committees}

From 2000FY, Categorized Committee changed the name to Technical Committee, and the Committees were grouped according to their activities, so they would correspond to the Technical Division (formerly Specialized Field Division) of the Academic Society, for the purpose of vitalizing exchange between industries and universities, as well as promoting suggestion of technological development issues. Also, the Committee information was, in principle, opened to public.

As shown in Table 7, the Meetings of the Committees in
2000FY concentrated on common and important subjects which were considered significant at this point, and active discussion were engaged.

As result of strengthening link between industry and university for technology creation, participation of university researchers to the Meetings of the Committees increased, and more Committees planned enthusiastic exchange, through joint organization with the Technical Divisions of the Academic Society and through two-way participation to various activities.

For the Committees which convened twice a year, one of the meetings might be arranged as one-day meeting dedicated to research discussion, panel discussions were held to nurture younger researchers, and all Committees, while attempting to lighten their load in accordance with their activities, worked to change their mode of operation to create a fruitful Committee.

The following 7 Technical Subcommittees, which are subordinate organizations of Technical Committees were created in 2000FY, and together with those which completed their activities in the fiscal year, 32 Technical Subcommittees were active.

- Technology for advanced use of steelmaking energy, step II (Steelmaking)

- Plant maintenance (Cold Strip)

- Rolling oil (Cold Strip)

- Survey of latest information on large section (Large Section)

- Future technology for energy saving and $\mathrm{CO}_{2}$ emission reduction in the iron and steel making process (Examination for technology of waste energy recovery) (Heat Economy Technology)

- Technology for no-trouble operation and maintenance cost reduction of BOF waste gas recovery system (Plant Engineering)

- Electro-magnetic ultrasonic sensor to expand ultra testing applications (Quality Control)

\subsection{Research Group}

In 2000FY, 6 Research Groups were created and 6 completed their activities. The objectives and results of each Group are shown in Table 7. Table 8 shows the continuing Research Groups (excluding those which started or finished in 2000FY).

\subsection{Interdisciplinary Technical Committee}

"Interdisciplinary Technical Committee on Desirable Steel Materials for Automobile (II)" and "Technical Investigation Committee on Suitable Steel Structure for Inhabitant's Individual Infills" were completed in 2000FY. Also in 2000FY, "Interdisciplinary Technical Committee on Phase-control Metallurgy and Properties in Modern Structural Steels" was newly formed (until 2002FY). 
ISIJ International, Vol. 41 (2001), No. 7

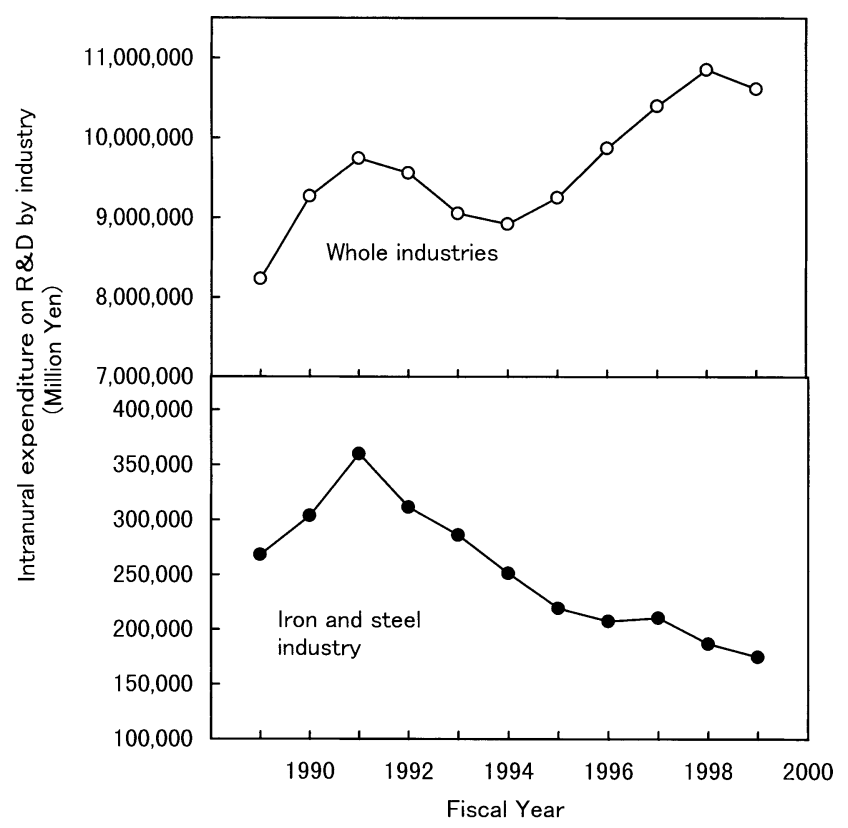

Fig. 4. Trend of Intranural expenditure on R\&D by industry.

Source: "Report on the 2000 Survey of the Research and Development", Statistics Bureau \& Statistics Center.

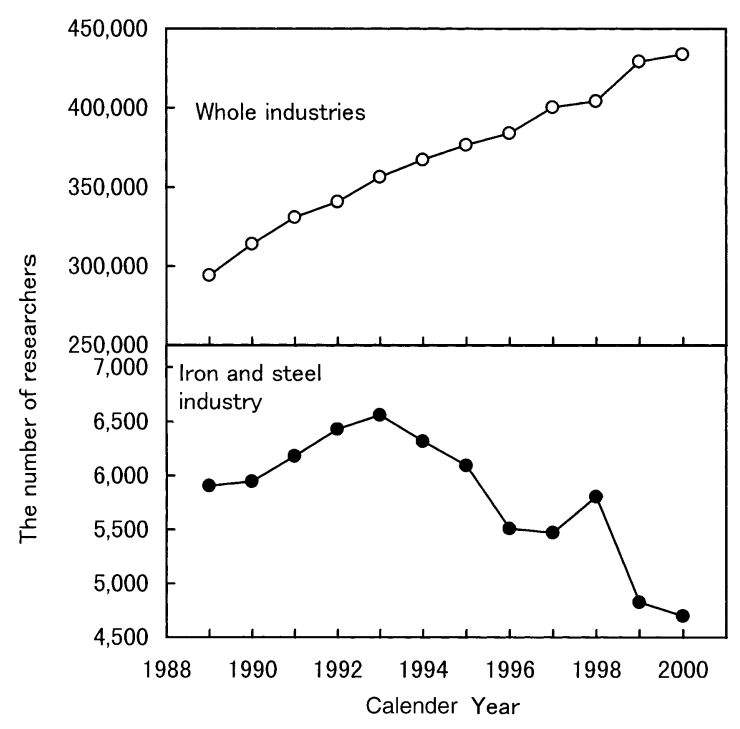

Fig. 5. Trend of the number of regular researcher.

Source: "Report on the 2000 Survey of the Research and Development", Statistics Bureau \& Statistics Center.

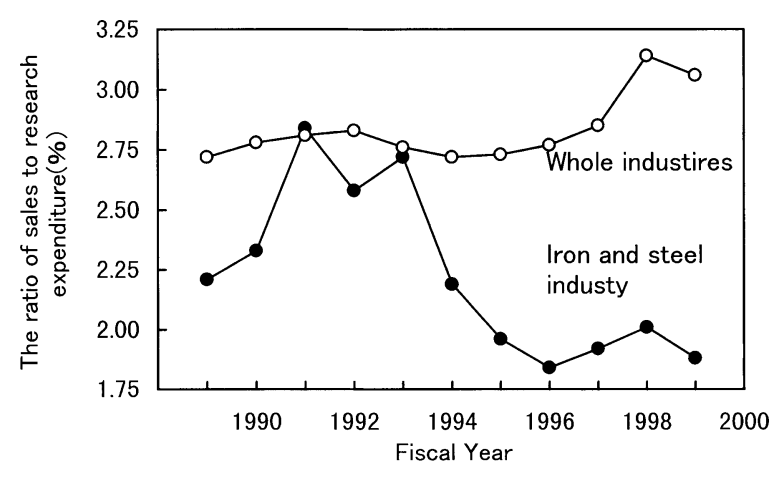

Fig. 6. Trend of the ratil of sales to research expenditure. Source: "Report on the 2000 Survey of the Research and Development", Statistics Bureau \& Statistics Center.

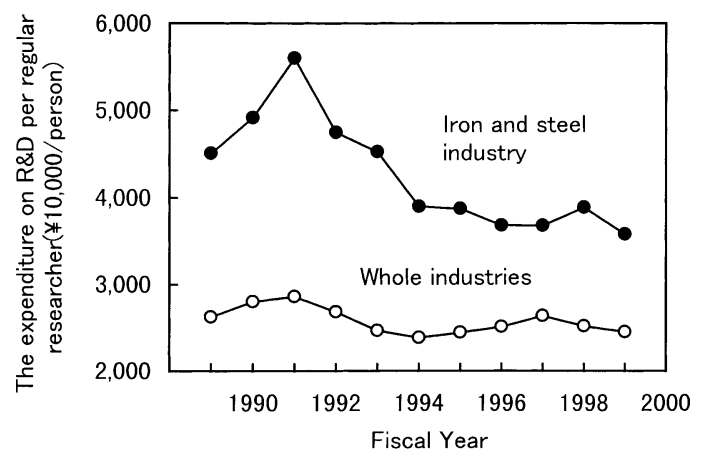

Fig. 7. Trend of the expenditure on R\&D per regular researcher. Source: "Report on the 2000 Survey of the Research and Development", Statistics Bureau \& Statistics Center.

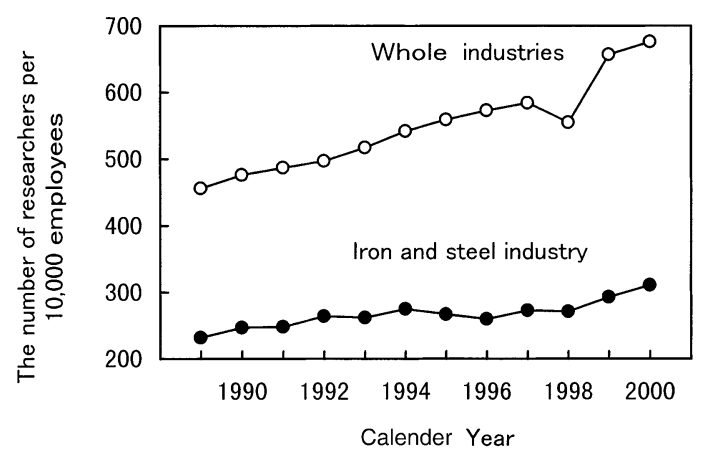

Fig. 8. Trend of the number of researchers per 10,000 employees.

Source: "Report on the 2000 Survey of the Research and Development", Statistics Bureau \& Statistics Center. 
Table 6. Activities of Technical Committee, Research Group, and Interdisciplinary Technical Committee engaging the technology creation in Technical.

\begin{tabular}{|l|l|}
\hline $\begin{array}{c}\text { Technology creation } \\
\text { activities }\end{array}$ & \multicolumn{1}{c|}{ Content of activities } \\
\hline Technical Committee & $\begin{array}{c}\text { To promote the exchange of technology information concerning iron and steel production with the aim of improving } \\
\text { the level of the conventional technologies, to extract technological tasks in each category and implement researches. } \\
\text { Twenty Committees cover all iron and steel production are established, and engineers and researchers from industry } \\
\text { and university researchers as well, are participating in each Committee. Meeting is held once or twice a year. } \\
\text { "Technical Subcommittees" that discuss technological problems are established as subordinate organization, and their } \\
\text { activities provide basis for technology creation. }\end{array}$ \\
\hline Research Group & $\begin{array}{l}\text { To conduct the joint research on specific and important subjects for iron and steel industry based on the needs form } \\
\text { industry and seeds from academia. }\end{array}$ \\
\hline $\begin{array}{l}\text { Interdisciplinary } \\
\text { Technical Committee }\end{array}$ & $\begin{array}{l}\text { To make technical examinations and surveys on future development and solution about interdisciplinary } \\
\text { technological problems within the iron and steel industry and with other industries. }\end{array}$ \\
\hline
\end{tabular}

Table 7. Activities of the Technical Committees in 2000FY.

\begin{tabular}{|c|c|}
\hline Committee on & $\begin{array}{l}\text { Common subject } \cdot \text { Particular subject } \cdot \text { Report from Technical Subcommittee } \\
\text { (1):Meeting in spring, (2)Meeting in autumn) }\end{array}$ \\
\hline Ironmaking & $\begin{array}{l}\text { (1) Changes in situation the surrounding sintering material and the } \\
\text { countermeasures }\end{array}$ \\
\hline Coke & (2)Maintenance of peripheral facilities of coke oven \\
\hline Steelmaking & $\begin{array}{l}\text { (1) Common subject "Work on high-speed and high-efficiency treatment in the } \\
\text { smelting process" } \\
\text { (2) Work on quality improvement of sub-billet, improvement of quality determination } \\
\text { technology, rationalization of refining process through improvement in refining } \\
\text { technology, simplification of billet refining process, and improvement of } \\
\text { distribution }\end{array}$ \\
\hline Electric Furnace & $\begin{array}{l}\text { (1) Common subject "On refining" } \\
\text { (2) Cost reduction in continuous casting }\end{array}$ \\
\hline Special Steel & $\begin{array}{l}\text { (1)Common subject "Recent quality improvements in carbon steel and high grade } \\
\text { wire and rod"; Report of Technical Subcommittee } \\
\text { (2) On status and issue of stainless manufacture }\end{array}$ \\
\hline Refractories & $\begin{array}{l}\text { (1) Panel discussion "Case studies of improvements in furnace building," "Current } \\
\text { status and future of wet gunning technology" } \\
\text { (2) Research report; Report of Technical Subcommittee on Technology for } \\
\text { Evaluation of Corrosion Resistance of Refractories (final report) }\end{array}$ \\
\hline Heavy Plate & $\begin{array}{l}\text { (1) Plant operation status report } \\
\text { (2)Plant operation status report; Group discussion - Staff Group "Chokko-ritsu*," } \\
\text { - Foremen Group "On improvement of "Chokko-ritsu*" on site" } \\
\text { (*ratio of products with non additional process to correct insufficient quality) }\end{array}$ \\
\hline Hot strip & $\begin{array}{l}\text { (1) Special lecture "Study on safety evaluation of high pressure pipeline for } \\
\text { transportation of natural gas"; Foremen's study group } \\
\text { (2)Plant operation status report; Free topic; Foremen's Investigation Group; Reports } \\
\text { of Technical Investigation Group }\end{array}$ \\
\hline Cold strip & $\begin{array}{l}\text { (1)Plant operation status report; Foremen Group - common subject "Increasing } \\
\text { productivity" } \\
\text { (2)Plant operation status report }\end{array}$ \\
\hline $\begin{array}{l}\text { Coated } \\
\text { Sheet }\end{array}$ & $\begin{array}{l}\text { (1) Plant specifications } \\
\text { (2) Plant operation status report }\end{array}$ \\
\hline Large Section & $\begin{array}{l}\text { (1) Special lecture "Amendments to Building Standard Laws and performance } \\
\text { demanded of steel materials" } \\
\text { (2) Special lecture "Toward creation of circulating society" }\end{array}$ \\
\hline $\begin{array}{l}\text { Medium and } \\
\text { Small Section }\end{array}$ & $\begin{array}{l}\text { (1) Subject research: A Group "Rationalization of manpower", B Group } \\
\text { "Improvement of rolling capacity", Foremen Group "On multipurpose operation" } \\
\text { (2)Plant operation status report }\end{array}$ \\
\hline Wires and Rods & $\begin{array}{l}\text { (1)Plant operation status report; Reports on open topic research } \\
\text { (2) Common subject "Facility for billet refining and its operation," "Facilities for } \\
\text { controlled rolling and controlled cooling and their operation"; Plant operation } \\
\text { status report; Foremen Group subject "Multipurpose operation" }\end{array}$ \\
\hline $\begin{array}{l}\text { Steel Pipes and } \\
\text { Tubes }\end{array}$ & $\begin{array}{l}\text { (1)Plant operation status report; Special lecture "Trends in future new energy" } \\
\text { (2)Report of Technical Subcommittee on Welding, Seamless, and HLP }\end{array}$ \\
\hline Rolling Theory & $\begin{array}{l}\text { (1) Common subject "On development of technology for sheets, plates, wires and rods } \\
\text { rolling; technology for steel pipe and tube rolling and forming; and related } \\
\text { technologies" } \\
\text { (2) Common subject "On development of technologies for sheet, plate, wire and rod } \\
\text { rolling; technologies for steel pipes and tubes rolling and forming; and related } \\
\text { technologies" }\end{array}$ \\
\hline $\begin{array}{l}\text { Heat Economy } \\
\text { Technology }\end{array}$ & (2)Integrated subject "Application technology for regenerative burner" \\
\hline $\begin{array}{l}\text { Control } \\
\text { Technology }\end{array}$ & $\begin{array}{l}\text { (1)Research report; Special session "Reports related to motor drive" "Trends in } \\
\text { information control technology and case studies of application" "Temperature } \\
\text { measurement technology" } \\
\text { (2) Special lecture "Trends in wireless application technology" "Trends in IT } \\
\text { technology"; Free discussion }\end{array}$ \\
\hline Plant Engineering & $\begin{array}{l}\text { (1) Report of Technical Subcommittee "Mechanical technology for reduction of } \\
\text { maintenance cost and extension of mechanical life on hot rolling"; Special lecture } \\
\text { "Pioneering Japan's future with new technology development" } \\
\text { (2) Technology and controlling of lubrication at steelworks }\end{array}$ \\
\hline Quality Control & $\begin{array}{l}\text { (1)(NDI ) Report of Technical Subcommittee; Regular survey of actual } \\
\text { status "Meeting bodies, related organization, number of workers" } \\
\text { (2) Machinery Testing Division: Regular work performance report; Report on case } \\
\text { studies of automation efficiency; Report of Technical Subcommittee }\end{array}$ \\
\hline $\begin{array}{l}\text { Analysis } \\
\text { Technology }\end{array}$ & $\begin{array}{l}\text { (1) Report of Technical Subcommittee } \\
\text { (2) Special lecture "Analysis of quantification standard of hydrogen in metals"; } \\
\text { Report of Technical Subcommittee }\end{array}$ \\
\hline
\end{tabular}


Table 8. Objectives of new Research Groups and results of Research Groups that completed activities in 2000FY.

\begin{tabular}{|c|c|c|c|}
\hline & Research Group & Objectives /Results of activities & $\begin{array}{l}\text { Activity term } \\
\text { (Fiscal Year) }\end{array}$ \\
\hline \multirow[t]{5}{*}{ New Group } & $\begin{array}{l}\text { Innovative High Efficiency } \\
\text { Refining Reactor Design }\end{array}$ & $\begin{array}{l}\text { To conduct research for the creation of new flow agitation, mixing, and separating } \\
\text { reactor to achieve high efficiency in hot metal refining reaction in desiliconization, } \\
\text { desulfurization, dephosphorization, inclusion floating, two phase mixture, and } \\
\text { others, regardless of ironmaking or non-ironmaking processes. }\end{array}$ & $2000 \sim 2003$ \\
\hline & $\begin{array}{l}\text { Development of New } \\
\text { Structural Material Using } \\
\text { Slag for the Improvement of } \\
\text { Urban Infrastructure }\end{array}$ & $\begin{array}{l}\text { With the target of developing prefabricated building material for building urban } \\
\text { infrastructure as regular usage for iron and steel slag, to clarify the conditions } \\
\text { (material performance and design) necessary as building materials for such use. } \\
\text { Also, to study the socio-engineering conditions for using such materials for building } \\
\text { urban infrastructure, and to review the conditions for creating new manufacture } \\
\text { industry for supplying prefabricated building material for building urban } \\
\text { infrastructure using iron and steel slag as main material. }\end{array}$ & $2000 \sim 2003$ \\
\hline & $\begin{array}{l}\text { Coating Microstructure and } \\
\text { Properties of Calvannealed } \\
\text { Steel Sheets }\end{array}$ & $\begin{array}{l}\text { For the development of superior melted plating material, 1) to clarify the } \\
\text { mechanism of alloy formation reaction, and 2) to create model of thin membrane } \\
\text { structure and to clarify the destruction mechanism. }\end{array}$ & $2000 \sim 2003$ \\
\hline & $\begin{array}{l}\text { Development of Skill-free } \\
\text { Technology for Chemical } \\
\text { Analysis Employed in Iron } \\
\text { and Steelmaking Process }\end{array}$ & $\begin{array}{l}\text { To conduct research and development of skill-free iron and steel wet chemical } \\
\text { analysis technology using FIA. Not only to accomplish communication and } \\
\text { maintenance of technology for iron and steel wet chemical analysis, but also to } \\
\text { establish the foundation for the development of chemical analysis technology which } \\
\text { can sufficiently respond to developments such as sophistication of iron and steel } \\
\text { process in the } 21 \text { st century and manufacture of high quality iron and steel products. }\end{array}$ & $2000 \sim 2003$ \\
\hline & $\begin{array}{l}\text { Prediction of Surface Defect } \\
\text { in Rolling Process }\end{array}$ & $\begin{array}{l}\text { To develop a projection technology for the occurrence and progression of surface } \\
\text { defect in heavy plates, hot-rolling of sheets, rod rolling, and shape rolling. Hot- } \\
\text { rolling will be taken up as representative of plate rolling, and rods as representative } \\
\text { of shape rolling. }\end{array}$ & $2000 \sim 2003$ \\
\hline $\begin{array}{l}\text { New and } \\
\text { Group } \\
\text { completed }\end{array}$ & $\begin{array}{l}\text { Agglomeration of Difficult- } \\
\text { to-Sintering Iron Ore }\end{array}$ & $\begin{array}{l}\text { To engage in basic research on agglomeration mechanism and to organize issues } \\
\text { which may link to limonite mixing technology, by focusing on technology for mixing } \\
\text { high volume of limonite under low slag condition ( } 60 \% \text { or more limonite content in } \\
\text { sintering material, } 5 \% \text { or less sintering ore SiO24). Since agglomeration reaction is } \\
\text { affected by ore conjugation and pseudo-particle structure of the material content, } \\
\text { basic research was conducted from two aspects of } 1 \text { ) agglomeration reaction and } 2) \\
\text { pseudo-particle structure. }\end{array}$ & 2000 \\
\hline \multirow[t]{5}{*}{$\begin{array}{l}\text { Group } \\
\text { completed }\end{array}$} & $\begin{array}{l}\text { Enhanced Process Tech- } \\
\text { nology in the Lower Part of } \\
\text { Blast Furnace }\end{array}$ & $\begin{array}{l}\text { The irregular activity of the four phases - gas, liquid, fine particle, and charged } \\
\text { particle - in the lower part of the furnace was analyzed, and their effects on heat } \\
\text { conductivity and reaction were clarified. The function of the lower part of the } \\
\text { furnace was strengthened by activating the furnace core, and the performance of } \\
\text { the blast furnace was dramatically improved in production elasticity, energy } \\
\text { conservation, environmental protection, use of inferior raw material, and increased } \\
\text { lifespan. }\end{array}$ & $1997 \sim 2000$ \\
\hline & $\begin{array}{l}\text { Modeling of Optical Surface } \\
\text { Properties of Steel Plates }\end{array}$ & $\begin{array}{l}\text { Simulation model was created to represent how optical property of reflection and } \\
\text { heat radiation changed, given the steel plate surface property such as material, } \\
\text { structure, and fine formation. This model provided the way to conduct efficient } \\
\text { research and development of principles and methods for measuring surface } \\
\text { properties online. }\end{array}$ & $1997 \sim 2000$ \\
\hline & $\begin{array}{l}\text { Formation Process of Micro- } \\
\text { structure due to the Phase } \\
\text { Decomposition }\end{array}$ & $\begin{array}{l}\text { Concentration was placed on diffused phase transformation (aging precipitation } \\
\text { phenomenon), which holds important position in material structure science, and } \\
\text { recent experimental and theoretical advances in this field, as well as the } \\
\text { relationship between structure formation of complex system and chaos theory were } \\
\text { discussed freely to deepen mutual understanding. }\end{array}$ & $1997 \sim 2000$ \\
\hline & $\begin{array}{l}\text { High-Speed Deformation of } \\
\text { Steels for Automotive Use }\end{array}$ & $\begin{array}{l}\text { Joint research was done and leading principle was obtained for the clarification of } \\
\text { metallurgical activity during high speed deformation such as during collision, } \\
\text { through 1) analysis and simulation of material deformation during collision, 2) } \\
\text { analysis of stress and distortion relationship of various materials under high speed } \\
\text { deformation and metallurgical consideration, and 3) extraction of material } \\
\text { parameters which represent high speed deformation activity and their evaluation } \\
\text { method. }\end{array}$ & $1997 \sim 2000$ \\
\hline & $\begin{array}{l}\text { Development of } \\
\text { Industrial Systems }\end{array}$ & $\begin{array}{l}\text { Work on environment and recycling issues such as the problems in iron and steel } \\
\text { industry and establishment of circulating society were reviewed, and indicators for } \\
\text { the creation of new industrial system was clarified. Direction of eco-system and } \\
\text { eco-material, technology as eco-process, and core competence analysis were } \\
\text { reviewed. }\end{array}$ & $1997 \sim 2000$ \\
\hline
\end{tabular}

Table 9. Research Groups in operation.

\begin{tabular}{|l|c|}
\hline \multicolumn{1}{|c|}{ Research Group on } & $\begin{array}{c}\text { Activity term } \\
\text { (Fiscal Year) }\end{array}$ \\
\hline Modeling and Optimization of Planning Problems in Steel Industry - Large Scale Complex Systems Approach - & $1998 \sim 20001$ \\
\hline Rapid and High Sensitivity Analysis for Steel Production Control & $1998 \sim 20001$ \\
\hline Coke Property & $1998 \sim 2001$ \\
\hline Advanced Application of Electromagnetic Forces to Materials Processing & $1999 \sim 20002$ \\
\hline Fixation of Waste $\mathrm{CO}_{2}$ with Algal Production Enhanced by Enrichment of Steelmaking Slag & $1999 \sim 2002$ \\
\hline Advanced Diagnosis and Control Techniques for Labor-Saving Based on a Large Quantity of Data & $1999 \sim 2002$ \\
\hline Elucidation of Behavior of Boron and Promotion of Its Usage in Steel & $1999 \sim 20002$ \\
\hline Precipitation Control in Steels & $1999 \sim 20002$ \\
\hline
\end{tabular}

\section{Acknowledgments}

The Author would like to acknowledge the assistance of the Ministry of Economy, Trade and Industry (Economic circumstance of the iron and steel industry), as the guid- ance of The Japan Iron Steel Federation (various statistics), major sustaining members of ISIJ, and the staff members of the ISIJ. 
Technologics, facilities, and products of the supporting member companies of ISIJ to pay attention from January to December 2000 are as follows.

\section{Ironmaking}

\section{Dust Recycling Facility Based on the Rotary Hearth Process}

\section{By Nippon Steel Corporation}

Nippon Steel Corporation has been energetically working on the enhanced recycling of generated substances as resources, on a company-wide basis. As part of the company's efforts to recycle dust generated in integrated steel manufacture, dust-recycling facilities based on the rotary furnace bed process are now in operation at Hirohata Works and Kimitsu Works.

Steelworks-generated dust, which used to be difficult to recycle because of its zinc content, can now be mixed with coal, granulated and dried, and subjected to high-temperature reduction at $1200-1300^{\circ} \mathrm{C}$ on the bed of a rotary furnace for dezincification in this dust-recycling facility, and recycled as reduced iron within the steelworks.

The dust-recycling facility at Hirohata Works has a capacity of treating 190000 tons/year of dust mainly from the steelmaking process, and reduced-iron pellets produced, while still hot, are conveyed and reused as steelmaking material.

The facility at Kimitsu Works has a capacity of treating 190000 tons/year of dust mainly generated from the ironand steelmaking processes, and high-strength reduced iron pellets produced are cooled and then reused as material for charging into blast furnaces.

Both facilities have achieved a reduction ratio and dezincification ratio of over $90 \%$. Oxidized zinc recovered separately is reused as a material for zinc.

These facilities make it possible to utilize dust generated at both steelworks and realize a reduction of treating costs.

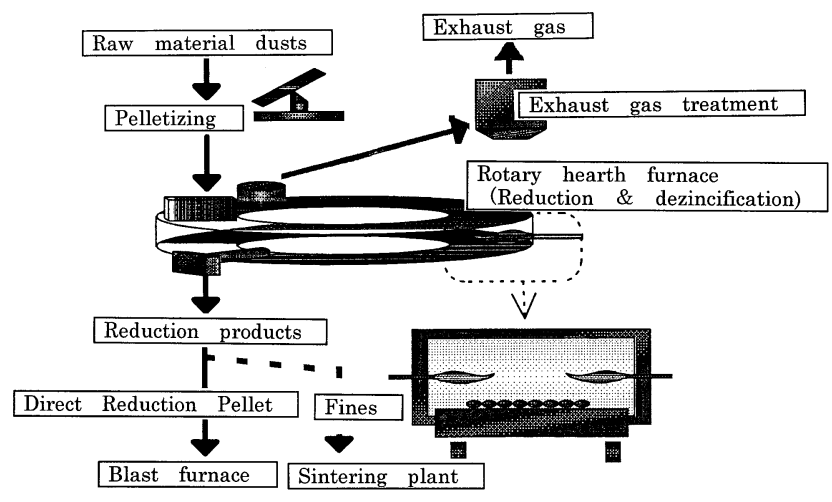

Duct recycling process flow.

\section{Coke Oven Waste Plastics Recycling Facilities By Nippon Steel Corporation}

Nippon Steel Corporation has in operation, at Nagoya Works and Kimitsu Works, pre-treating facilities which allow recycling in existing coke ovens waste container and packaging plastics as chemical feedstock. Waste container and packaging plastics, collected by the local governments, are pre-treated and formed into $20 \mathrm{~mm}$ pellets to facilitate reaction, and then mixed with coal and charged in the cokeovens. In the initial year, this process at both works treated 20000 tons.

Waste plastics, when mixed with coal and charged into the coke-ovens having high temperatures and free from oxygen, become light oil, coke-oven gas and coke, which are then re-utilized as chemical feedstock, fuel, and reducing agent for blast furnaces, respectively. This coke oven process of converting waste container and packaging plastics into new resources is one of the specific measures taken to reduce global-warming gas emissions from steelworks under the Voluntary Action Program formulated by the Japan Iron and Steel Federation in 1997. Nippon Steel intends to continue its efforts to increase its recycling capacities in the future.
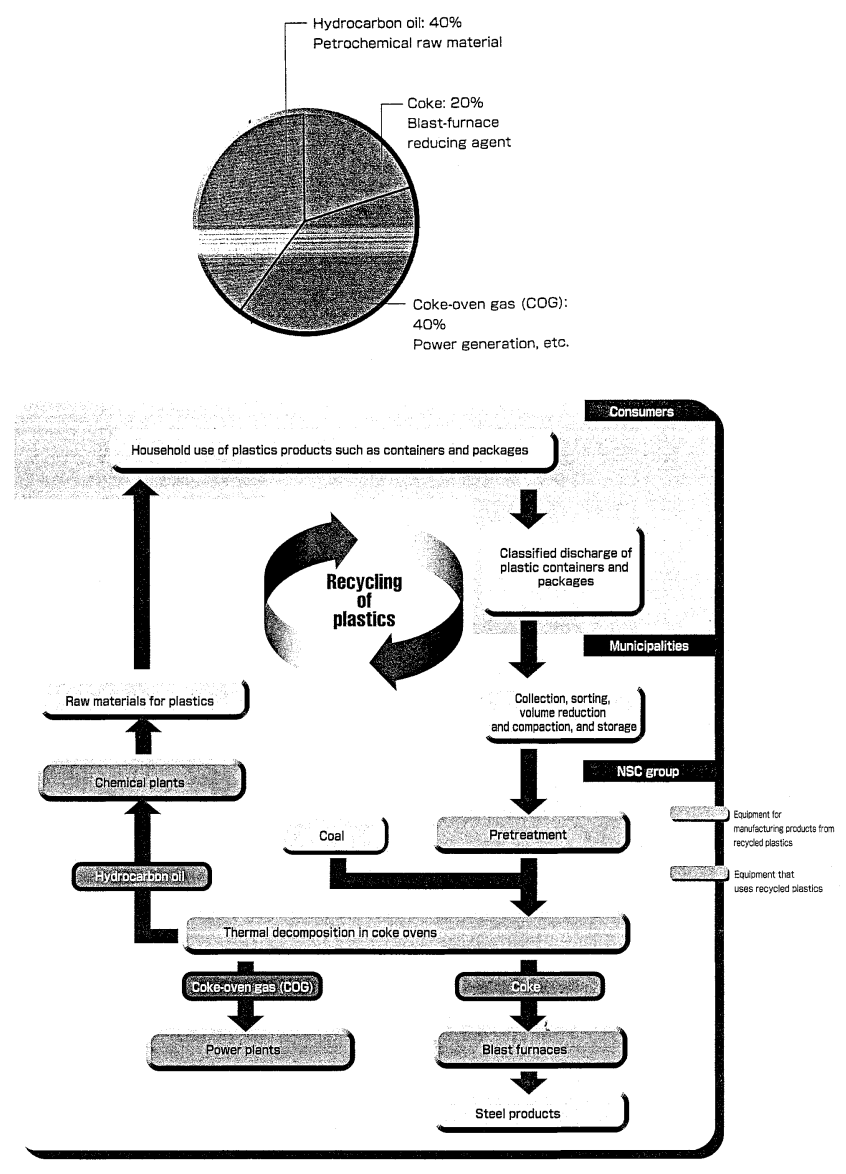

Utilization flow of coke oven waste plastics.

\section{Strategic Use of New Functions of Chiba Works No. 6 Blast Furnace}

By Kawasaki Steel Corporation

Kawasaki Steel Corporation developed new charging equipment and a new casting system under the slogan "development of a competitive blast furnace through the $21 \mathrm{st}$ century" and realized these technologies in a practical operation at Chiba Works No. 6 BF, which was relined in March 1998. Operational tests during the period of approximately 
$11 / 2$ years since the relining have confirmed the new functions and effects of the newly developed charging equipment, and a technology for remote casting operation was established with the new casting system.

The charging equipment is the same type of 3-parallel bunker bell-less top as that at the company's Mizushima Works No. 3 BF. However, at No. 6 BF, a normal/reverse tiling chute for the rotating chute and a material flow control device for control of the charging material flow were introduced, making it possible to charge and lay multiple types of raw materials stably and with high accuracy. By utilizing these functions, a high charging ratio of inexpensive fine raw materials and large reduction in the ratio of expensive sintered ore have been realized. (An agglomerated ore ratio of $66.9 \%$ was achieved in February 2000.)

In the construction of the new casting system, the plant operation room (cast house operation room) where remote operation of the casting equipment and monitoring of the condition of automatic operation are performed and the monitoring and operation room (control room) where blast furnace and hot stove operation are conducted were unified and consolidated, reducing manning to $2 / 3$ of the conventional number. In the development of automation equipment, a tap hole opener controlled by AI was developed and installed to automate tap hole opening work. In combination with this, a full-flat cast house was adopted to improve work efficiency on the casting floor and a new type vortex dust collector was installed to improve the working environment with good results.

At Chiba No. 6 BF, the development and strategic use of the new charging equipment and new casting system described above have realized a high charging ratio of inexpensive ore, high quality hot metal, improved manpower efficiency, and other benefits.

\section{Steelmaking}

\section{Introduction of Iron Reserve Barrel with Induction Heater}

\section{By Nippon Steel Corporation}

Nippon Steel Corporation has introduced to No. 3 steelmaking plant of Yawata Works an iron reserve barrel (IRB) equipped with induction heaters based on the superheater ${ }^{1)}$ of ISCOR of South Africa, to level the hot metal balance between iron- and steelmaking facilities and supplement BOF heat source.

Yawata IRB can store a maximum of 2000 tons of hot metal. Equipped with six channel-induction heaters with 4.5-MW max. current per heater, it can melt charged steel scrap within the hot metal temperature range utilizing carburizing reaction.

Features of IRB include smaller power capacity than that of electric arc furnace thanks to continuous power application and high energy efficiency. Our operation at maximum current application confirmed that energy efficiency was $85 \%$ or higher (taking into account radiation from IRB body) and scrap and cold pig iron melting capacity amounted to 1 ton per minute. Operation is simplified, requiring only one operator.

At present, Yawata IRB is operating smoothly, acting as a buffer to adjust operation efficiencies $(\mathrm{t} / \mathrm{hr})$ of blast furnace and $\mathrm{BOF} / \mathrm{CC}$. It also contributes to the stabilization of BOF operation by controlling increases or decreases in BOF hot metal ratio by adjusting scrap and cold pig iron melting in IRB. The equipment also contributes to reducing carbon dioxide emission because it can melt steel scrap at high energy efficiency.

1) Superheating for Oxygen Steelmaking, Steel Times (Oct. 1978), P853

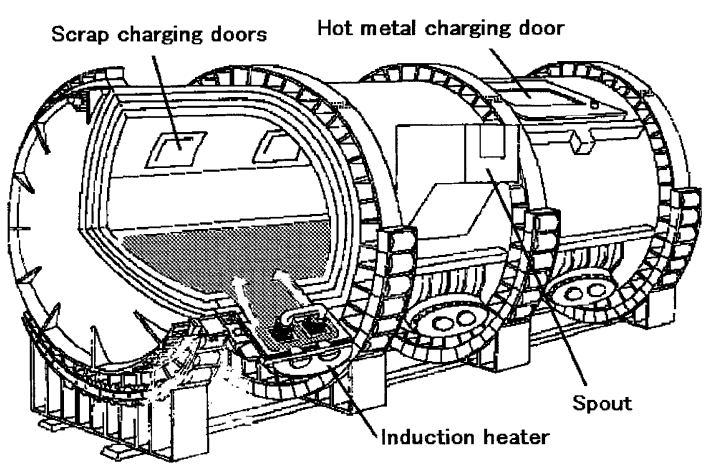

Schematic view of IRB.

\section{Completion of Minimal Slag Operation at BOF By NKK Corporation}

The hot metal pretreatment processes, especially dephosphorization in advance of decarburization at the BOF, has been developed and applied in practice for the demand of mass production of high quality steel, energy/resource saving and minimization of discharged slag, since the 1980s in Japan.

NKK has achieved a minimal slag operation with the installation of a preliminary desiliconization process in the transfer ladle to the level of negligible silicon content; as well as the development of both desiliconization technology and silicon-free dephosphorization processes with high productivity enabling a dephosphorization-free BOF operation.

This development realized the minimal discharge of slag from the steelmaking process, and an improvement in productivity of the BOF by $20 \%$ at the same time. Fukuyama Works achieved 10 million metric tons production per annum with 3 BOFs for the demand of increase in production of steel.

Allowing not only less discharge of slag from the steel-

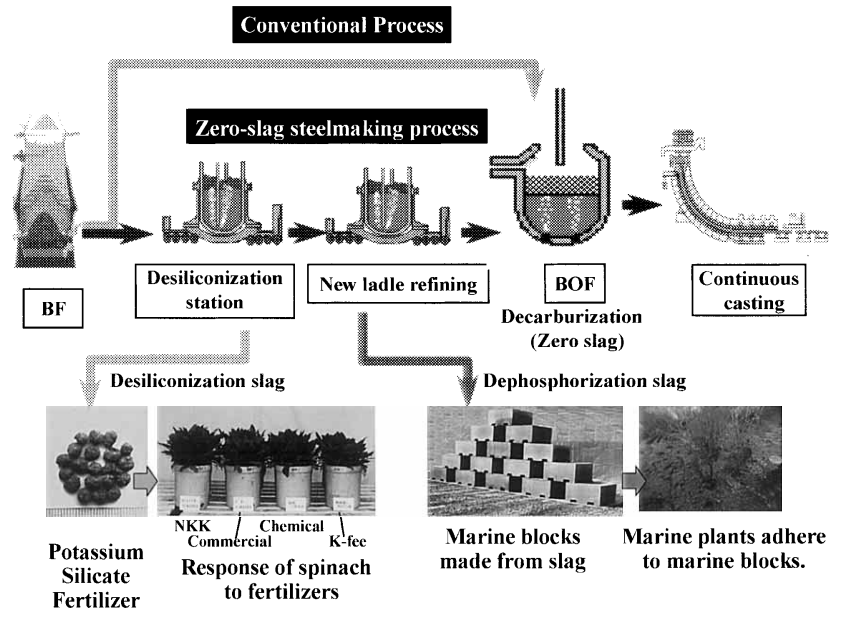

Zero-slag steelmaking process. 
making process, this process also allows promotion of slag utilization as alternative resources, because of the complete separation of slag from every process and its simple composition. Desiliconization slag, mainly consists of silica, is used for raw material for slow-release potassium silicate fertilizer, for example, and dephosphorization slag is used for marine usage blocks carbonated with $\mathrm{CO}_{2}$ of exhaust gas.

\section{Hot-rolling Strip Mill}

\section{Construction and Start-up of the Nakayama Plate and Hot Strip Mill}

by Nakayama Steel Works Ltd.

Nakayama Steel Works Ltd. constructed new plate and hot strip mill in Funamachi Works Osaka. Nakayama decided that the hoop mill, the section and plate mill and 3-Hi medium plate mill should be consolidated to new one mill.

The new plate and hot strip mill has some special features as follows;

1. It is the most compact conventional type hot strip mill in the world. The length between the reheating furnace and the coiler is under $200 \mathrm{~m}$.

2. It is the combination mill for hot strip and plate production.

3. It is equipped with all the newest technologies for stable production and excellent product quality.

Main Technical Date

Coil Size: Thickness; $\quad 1.6 \mathrm{~mm}-16 \mathrm{~mm}$

Width; $\quad 600 \mathrm{~mm}-1550 \mathrm{~mm}$

Plate Size: $\quad$ Thickness; $16 \mathrm{~mm}-40 \mathrm{~mm}$

Width; $\quad 850 \mathrm{~mm}-1500 \mathrm{~mm}$

Annual Capacity: 840000 tons

Main specifications are as follows;

- It consists of 1 reheating furnace, 1 reversing rougher with attached edger, 6 finishers, 1 coiler and a plate finishing line.

- The reheating furnace has all low $\mathrm{NO}_{x}$ regenerative-type side burners.

- Rougher has a capacity of $9000 \mathrm{kw} \mathrm{AC.}$

- Features of finisher stands are follows; hydraulic AGC, low inertia hydraulic looper, roller bearing with an oil air

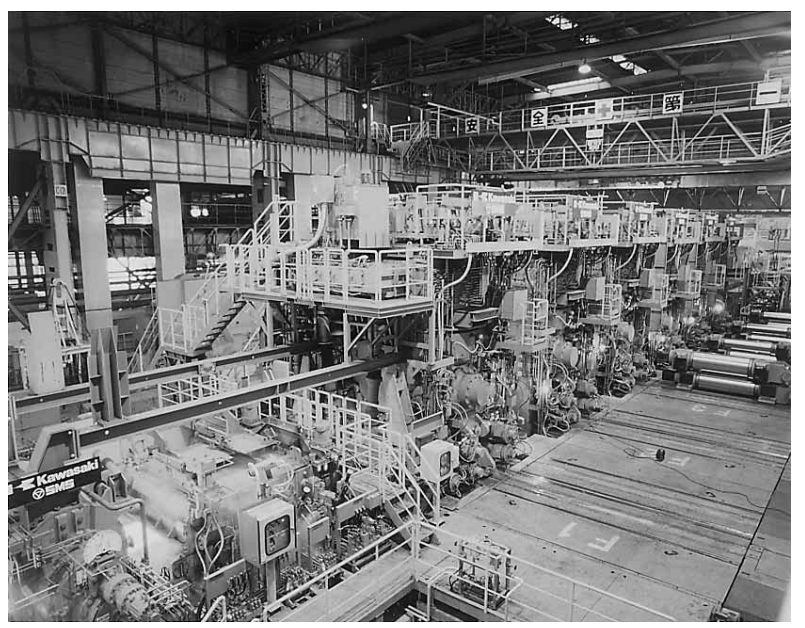

Funamachi Plate and Hot Strip Mill. lubrication system at back up roll, CVC rolling and small work roll diameter at last three stands.

The commissioning of new mill was started in January 2000 and successfully done. The monthly production reached up to 70000 tons in August 2000. The excellent product quality such as good tolerance, small crown and edge drop and high accuracy of finishing and coiler temperature has been achieved by the newest technologies.

\section{Cold Rolling Steel-Surface Treatment}

\section{New $440 \mathrm{~N} / \mathrm{mm}^{2}$ Grade High-Strength Steel Sheets with Fine Grain Structures for Auto Panel Use (SFG-HITEN)}

By NKK Corporation

NKK Corporation has developed a new $440 \mathrm{~N} / \mathrm{mm}^{2}$ grade high-strength steel sheets for use in automobile panels. Marketed as SFG-HITEN, the new Super-Fine-Grain (SFG) steel excels in both formability and galvannealed quality.

$440 \mathrm{~N} / \mathrm{mm}^{2}$ grade high-strength steel sheets with good formability have been developed based on ultra-low carbon IF (interstitial free) steel, in which the major strengthening method was solid-solution hardening with silicon, manganese and phosphorus. These sheets, however, had deterioration in galvannealed quality due to the high containment of solid-solution elements. This has limited the grade of commercially produced high-strength IF steel sheets to a maximum of $370 \mathrm{~N} / \mathrm{mm}^{2}$. And the mean $r$-value of the conventional steel was lower.

To overcome this hurdle, NKK has applied a unique strengthening technology, which combines grain refinement hardening and dispersing fine carbide (precipitation hardening). The SFG-HITEN has been developed by increasing the carbon content to three times the level ( $60 \mathrm{ppm})$ of conventional IF steels and the niobium content to almost twice at atomic percent.

The new $440 \mathrm{~N} / \mathrm{mm}^{2}$ grade hot-dip galvannealed steel sheet for use in automobile panels was achieved due to the reduced amount of solid-solution elements. Despite of the grain refinement, the mean $r$-value 1.7 (hot-dip galvannealed) was obtained by the texture control(developmet) and grain refinement of hot-bands. And the secondary work-embrittlement in the galvannealed sheets was improved by grain refinement of microstructure.

NKK is now able to mass-produce a series of cold-rolled

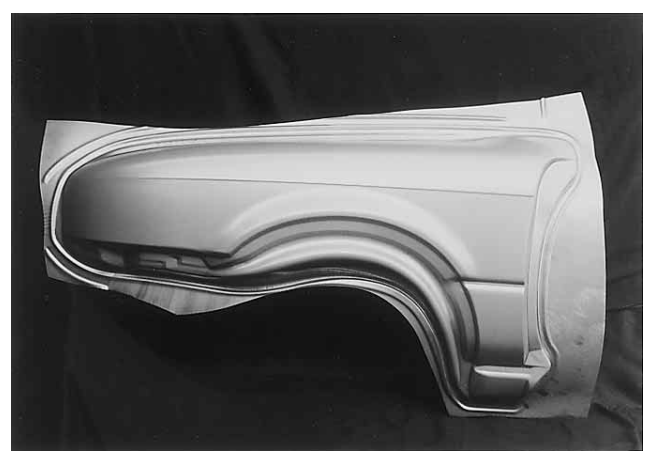

Automobile front fender stamped by NKK's 1200 -ton mechanical press (material:SFG440-GA). 
and galvannealed SFG-HITEN with grades ranging from $340 \mathrm{~N} / \mathrm{mm}^{2}$ to $440 \mathrm{~N} / \mathrm{mm}^{2}$. The new steels are stepping up widely applied into automobile panels, such as side-panel and door, which have been difficult to avail in hot-dip galvannealed high-strength steel sheets.

\section{The Fiber Coat Steel Sheet}

\section{By Sumitomo Metal Industries, Ltd}

Sumitomo Metal Industries, Ltd. has developed the fiber coated steel sheet in coil electrostaticaly on the hot dip galvanizing steel sheet cooperated with both Sumitomo Corporation and Mesac which produces the equipment of electrostatic fiber coating.

The name of new product is the Fiber Coat. The adhesive agent is applied on the hot dip galvanized steel coil continuously by roll coater. Then after the coil is covered with short nylon fiber electrostaticaly, it will be baked in the oven. As the fiber prevents dropping the dew, the Fiber Coat greatly exhibits the advantageous features applied in the air conditioning duct. From now on application to the appliance and structure will be progressed utilizing the attractive surface and function of keeping dew.

Advantageous features are as follows applying the Fiber Coat to the air conditioning duct,

1. Because it is unnecessary to use the heat-insulating material such as glasswool preventing dew drop, the cost dramatically decrease with shortage of construction period and reduction of the work cost.

2. The space of the heat-insulating material will be saved. It has the potential of larger effective usage above the ceiling and high ceiling height can be attained.

3. It is possible to apply a spiral duct with using the Fiber Coat coil which is realized in this development.

4. The Fiber Coat coil is made of an excellent recyclable materials. Therefore the Fiber Coat will reduce the industrial waste such as glasswool for heat-insulating material, and will be recycled as the normal steel scrap.

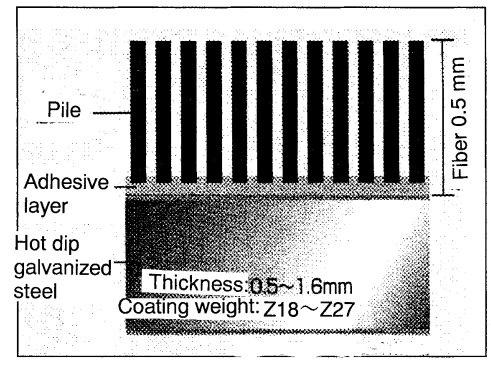

Cross section of fiber coat

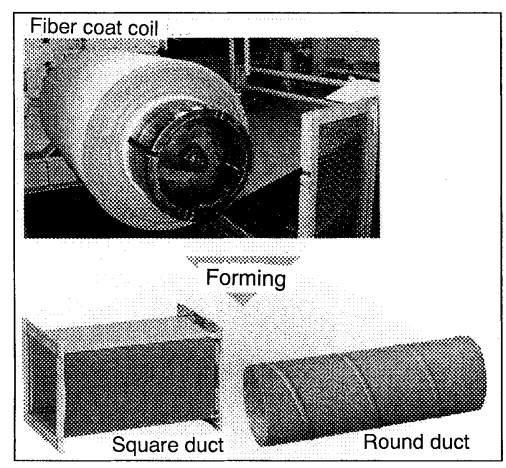

Fiber coat coil and air conditioning duct.

\section{Cold-rolling Mill and Continuous Galvanizing Line in Toyo Works Coming on Stream \\ By Nisshin Steel Co., Ltd.}

At our recently-constructed Toyo Works in Toyo City, Ehime Pref., subsequently to the commencement of operations of the world's first pickling line equipped with prerolling functions in October 1999, the cold-rolling mill and the continuous galvanizing line were commissioned in April and May 2000, respectively.

The cold-rolling mill is linked to the pickling line, and it is a continuous tandem configuration featuring its compactness and high performance with 6-hi mills using small diameter work rolls for all stands. Especially by adopting our original sheet-crown control system and the latest automatic-gauge control system, we have achieved eminent improvement of the gauge performance and high controllability of sheet-crown that meets the needs of our customers.

Also, with the combination of the vertical furnace equipped with the direct-fired burners and the horizontal furnace equipped with the radiant heating tubes, we have attained the compactness of annealing furnace and high response, easy operations and improved product quality. Furthermore, "ZAM", newly developed, super-corrosionresistant zinc-aluminum-magnesium-coated steel, is on commercial run. Thus we are now able to offer four types of coated steel sheet products.

Following the start-up of the Toyo equipment, we stopped operating a cold-rolling mill in Sakai Works (5TM: 5 stand Tandem Mill, started in 1963) in May 2000, and a continuous hot-dip galvanizing line in Ichikawa Works (No. 2 CGL: No. 2 continuous galvanizing line, started in 1965) in December 2000.

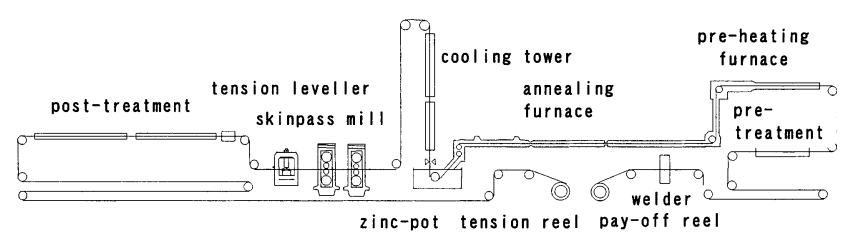

[Main specifications]

Size : $0.8 \sim 6.0 \mathrm{~mm}^{\mathrm{t}} \times 580 \sim 1350 \mathrm{~mm}^{\mathrm{w}}$

Line speed : Max. $150 \mathrm{mpm}$

Product Capacity : 40,000 MT/month

Continuous galvanizing line.

\section{Others}

\section{New Quality Guarantee System for Steel Sheets with Automatic Surface Inspector and Marking Equipment}

\section{By NKK Corporation}

NKK Corporation has developed a new quality guarantee system for steel sheets using a new type of automatic surface inspector and an automatic marking system named 'NKK-DeltaEye'. The newly developed inspector applies a unique polarization optical system.

For in-line inspection of steel sheet under processing, 
laser-type inspectors and CCD-type inspectors are widely used. However,those conventional systems have become inadequate for high level inspection of smaller and shallower defects which are recently requested to detect by the customers.

In the new inspector, a polarized sheet-like beam for the light source and three CCD-cameras with differently polarizing filters in a set in the detection part are used. This optical system is very sensitive to alternation of the state of reflected light from the surface, and it can get more information in comparison with conventional systems. Consequently, it works quite well on detection for small defects and shallow defects which are difficult to distinguish from the normal surface by conventional systems. Its detection rate is almost $100 \%$ and over-detection rate is very low.

Actually, this system includes high-speed image-processing units, and does automatic real-time inspection. In addition, it also has an automatic marking system which is linked to the inspector to mark over detected defects on the steel sheet under processing in order to display the defects to operators on the customer's side.

Using the new quality guarantee system, we mark certain defects on steel coils and ship to the customers. This system alters conventional guarantee system in which defects are completely rejected, and both customers and steel makers get merits as follows,

(1) Reducing average coil weight, handling efforts decrease and production efficiency increases.

(2) Precise inspection efforts on the customer's side after pressing process are made easier because of the clear

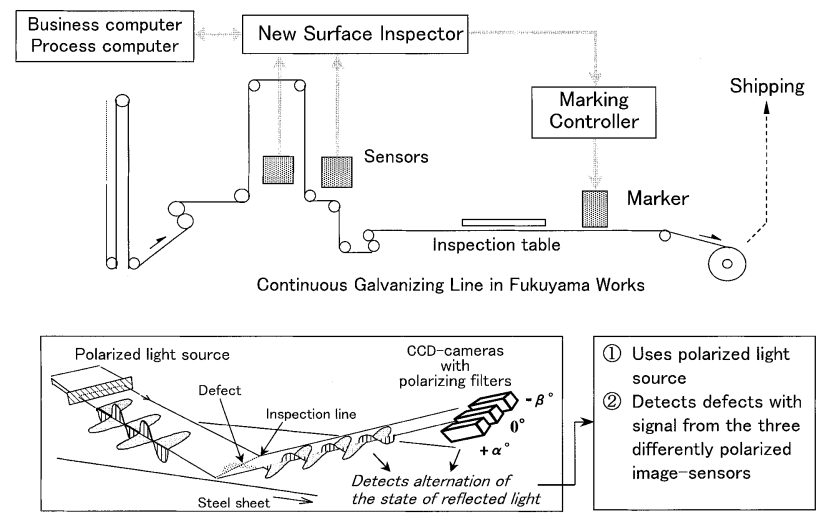

Schematic view of the new quality guarantee system. display of defects.

NKK has operated this system since 1999 at a continuous galvanizing line in Fukuyama Works, and further applications are being proceeded.

\section{Patchwork Tailored Blank \\ By Sumitomo Metal Industries, Ltd.}

Sumitomo Metal Industries, Ltd. has developed a new tailored blank technique to reduce the weight of the car. A tailored blank is a welded blank for stampings, composing of sheets of different thickness and/or strength. It achieves the reduction of die cost and assemblage cost by reducing the number of press parts and is applied to the various kinds of component, such as door inner and front side member.

Sumitomo Metals has further improved this technology and developed a patchwork tailored blank technique, where a piece of sheet is fillet-welded onto the area of the blank in order to increase strength. Because this technique does not require butt-welding, it is not necessary to cut the sheet precisely. The patchwork tailored blank increases a degree of freedom in designing tailored blank. Both linear and curved configuration weldings are possible. Regarding to welding method, seam laser welding is preferable to spot welding in terms of the press formability. The YAG laser welding is the most suitable for the patchwork tailored blank, because the laser beam can be transferred through the optical fiber enabling the robot to weld the blank with the complicated weld line at high speed.

Sumitomo Metals can support the total technology in introducing the patchwork tailored blanking including not only the welding condition of YAG laser but also the facility of the tailored blank, and is currently collaborating with a few Japanese car makers to put into practical use.

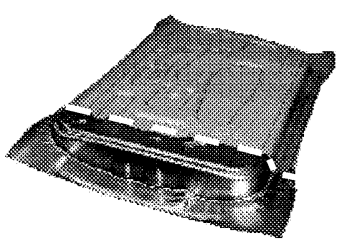

Conventional TB.

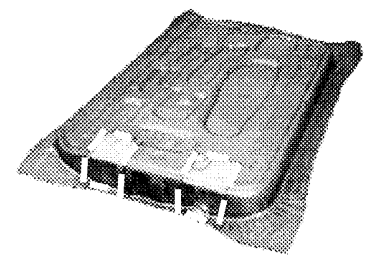

Patchwork TB. 